\title{
Experimental Study on Effect of Lime and Cement Stabilizers on Geotechnical Properties of Lateritic Soil
}

\author{
Audu, H.A.P. ${ }^{1}$ and Okovido J. O. ${ }^{2}$ \\ ${ }^{1,2}$ Department of Civil Engineering \\ University of Benin, Benin City, Edo State
}

Nigeria

\begin{abstract}
This study examined the effect of lime and cement as stabilizers on the geotechnical properties of the lateritic soil in Ogiso quarters, Benin City, Edo state of Nigeria. The lateritic soil samples, which were obtained from the street prone to erosion in Ogiso quarters, using the disturbed sampling method, were transported to the Geotechnical laboratory Department of Civil Engineering, University of Benin. The preliminary tests were performed on the samples for classification and identification purposes using the American Association of State Highway and Transportation Officials (AASHTO) classification system. They were stabilized using lime and cement stabilizers at $2,4,6,8$ and $10 \%$ by weight of the soil samples so as to analyze the performance of the stabilized agents on the lateritic soil. The laboratory tests, which included natural moisture content, specific gravity, particle sieve analysis, Atterberg limits, compaction and California bearing ratio (CBR) were carried out in accordance with the British standard (BS) method of test for soil in Civil Engineering. The result of the study has shown that the lateritic soil in the sample location is reddish brown in colour and belong to A-2-6 group with liquid limit, plastic limit and plasticity index values obtained as $33.20 \%, 14.14 \%$ and $19.06 \%$ respectively. The specific gravity of the soil sample is 2.53 . The natural moisture content is $15.1 \%$. The Optimum moisture content (OMC) and Maximum dry density (MDD) are $13.3 \%$ and $1.75 \mathrm{~g} / \mathrm{cm}^{3}$ respectively. The CBR values increased from $29.92 \%$ at $0 \%$ to a peak value of $191.8 \%$ at $6 \%, 119.57 \%$ at $8 \%$ and $135.36 \%$ at $6 \%$ for cement, lime and the combination of cement and lime respectively in the treated samples. These values indicate that the lateritic soil in the study area meets the general standard acceptable limit for construction of embankments, as they are in conformity with the Federal Ministry of Work (FMW) general standard acceptable limit for construction of embankments and sub-grade. The results of the tests in this study showed that the treatment of the lateritic soil has improved its strength and physical properties.
\end{abstract}

Key words: Lateritic soil, Soil stabilization, Stabilizing agents, Moisture content, California bearing ratio.

\subsection{INTRODUCTION}

In civil engineering, the engineers are faced with the challenges of providing very suitable materials for highway construction. They are interested in understanding the behavior of soil in solving engineering and environmental challenges, especially expansive lateritic soils that can cause significant damage to highway construction [1, 2]. It is quite common, in countries with tropical climate, that the soil found in the construction site do not satisfy the technical requirements of the project [3]. Infrastructural development is one of the major challenges in developing countries, which are located mostly in the tropics where lateritic soils are abundant and widely used in construction works.

In this modern age, driven by Information and Communication Technology, most communities, states and countries are trying to meet up with current globally accepted best practices. The geotechnical field of civil engineering finds itself in this stream of activities. Most available soils do not have adequate engineering properties to bear the expected load. Improvement of soil is the most practical and cheapest way of enhancing the strength and permeability of soil with the increased global demand for aggregate.

The most common materials used for construction in Nigeria are the lateritic soils because they occur naturally with intense weathering. Lateritic soils are deep brown (reddish brown) soils of cellular structure with lower concentration of oxides, easy to 
excavate but gets hardened on exposure to air owing to the motion of hydrated iron oxides, and these soils play very important roles in the construction industry worldwide and sometimes, there is need to improve the properties of the available soils [4, 5, 6]. Lateritic soils are used for base and sub-base materials, particularly when modified with lime, cement or bitumen [7].When red lateritic soils are used for underlying layer of highway pavement construction, the desiccation cracks experience by these underlying layers do reflect on the pavement. These cracks cause numerous problems in the pavement including reduction in shear strength, loss of water proofing and loss of roughness level [8]. So, provisions have to be made to make the soil better which leads to "soil stabilization". Unstabilised soil mixture can neither be used for a base construction nor provide adequate support base nor prevent wearing of the surface [9]. Natural soil is treated in order to improve its engineering properties and performance. The improvement can be in the form of grading, drainage, compaction and stabilization. The essence of soil stabilization is to change or improve soil properties like strength, workability, swelling potentials [10].

Soil stabilization is any treatment applied to a problem soil to improve its strength and reduce its vulnerability to water. It is a substantial improvement of the mechanical behavior and mechanical strength using low content of stabilizer. It is the process of mixing additives with soil to improve its volume stability, strength, permeability and durability [11, 12, 13]. Soil stabilization was defined by [7] as soil improvement technique in which the resistance of the soil to various types of deformation and forces is increased. Some materials have been used as stabilizing agents in the past. The most commonly used agents are Portland cement, asphalt binders and lime. Lime, the oldest traditional chemical stabilizer used for soil stabilization, is gotten from limestone by heating and combining it with water. It increases sub-grade stiffness, reduce the plasticity index of in-situ pavement material, and enhance volume stability [14]. Cement is a binder material, a substance that sets and hardens and can bind other materials together. It is usually mixed with other materials and water. Soil stabilization is used to reduce the permeability and compressibility of soil mass in earth structures and to increase its shear strength. It is required to increase the bearing capacity of foundation soils, to improve the natural soils for the construction of highways and airfield [15].

This study would help the tropical regions in the view of durability, and strengthen soils in erosion prone environment. The essence is to provide a soil mixture that would be good for construction of civil engineering infrastructure i.e. road construction, etc. Furthermore, evaluating the effect of stabilization agent on the geotechnical properties of lateritic soil would help to determine which of the stabilizing agent is more effective, cheaper and easy to use. The objectives of this study are to determine the geotechnical properties of lateritic soil: when collected at natural form, when stabilized with lime and cement, when lime and cement are mixed together; compare the effect of lime and cement when added to lateritic soil; ascertain the optimum lime and optimum cement needed for stabilization of the collected lateritic soil.

\subsection{RESEARCH METHODOLOGY}

\subsection{The Sample Location}

The study area is located at Ogiso quarters in Oredo local government area of Benin City, Edo State of Nigeria. It lies between latitude $6^{\circ} 15^{\prime} 22.5^{\prime \prime} \mathrm{N}-6^{\circ} 28^{\prime} 25.6^{\prime \prime} \mathrm{N}$ and longitude $5^{\circ} 32^{\prime} 35.6^{\prime \prime} \mathrm{E}-5^{\circ} 42^{\prime} 35.6^{\prime \prime E}$ in Edo State. It is an erosion prone area.

\subsection{Materials and Methods}

The lateritic soil samples, which were obtained from Ogiso quarters, using the disturbed sampling method, were transported to the Geotechnical laboratory Department of Civil Engineering, University of Benin. The samples were dried for 7days.The preliminary tests were performed on the samples for classification and identification purposes using AASHTO classification system [16]. They were stabilized using lime and cement stabilizers at 2,4,6,8 and $10 \%$ by weight of the soil samples in order to analyze the performance of the stabilized agents on the lateritic soil. The laboratory tests, which included natural moisture content, specific gravity, particle sieve analysis, Atterberg limits, compaction and California bearing ratio (CBR) were carried out in accordance with the specifications of the British standard (BS) method of testing for soil for Civil Engineering purposes, BS 1377 [17].

In order to determine the Atterberg limit of the lateritic soil sample, the soil samples that passed through a $0.425 \mathrm{~mm}$ sieve size were mixed with distilled water to form a uniform paste. The samples were left for 24 hours. Thereafter, the various consistency limit tests, such as liquid limit, plastic limit and plastic index were determined. The compaction test was carried out by weighing $3 \mathrm{~kg}$ of the soil samples mixed thoroughly with water starting with $5 \%$ by mass of the soil sample and compacted in three layers with each layer given 25 blows. Subsequent compactions were carried out on the sample using $2 \%$ by mass. The weight of the mould and its volume were also noted. The detailed procedure of this experiment is as it is recorded vividly in British Standard (BS) 1377: 1990 part 4 [17]. 


\subsection{RESULTS AND DISCUSSION}

\subsection{Classification of the soil}

The particle size analysis is presented in Fig.1. From the grain size analysis of the samples, the percentage passing no 200 sieve is $34.29 \%$, this implies that the material falls between class A-1 to A3, the liquid limit is 33.20 which is less than $(<) 40$ and the plasticity index is 19.06 which is greater than $(>) 11$. This implies that the soil is A-26.

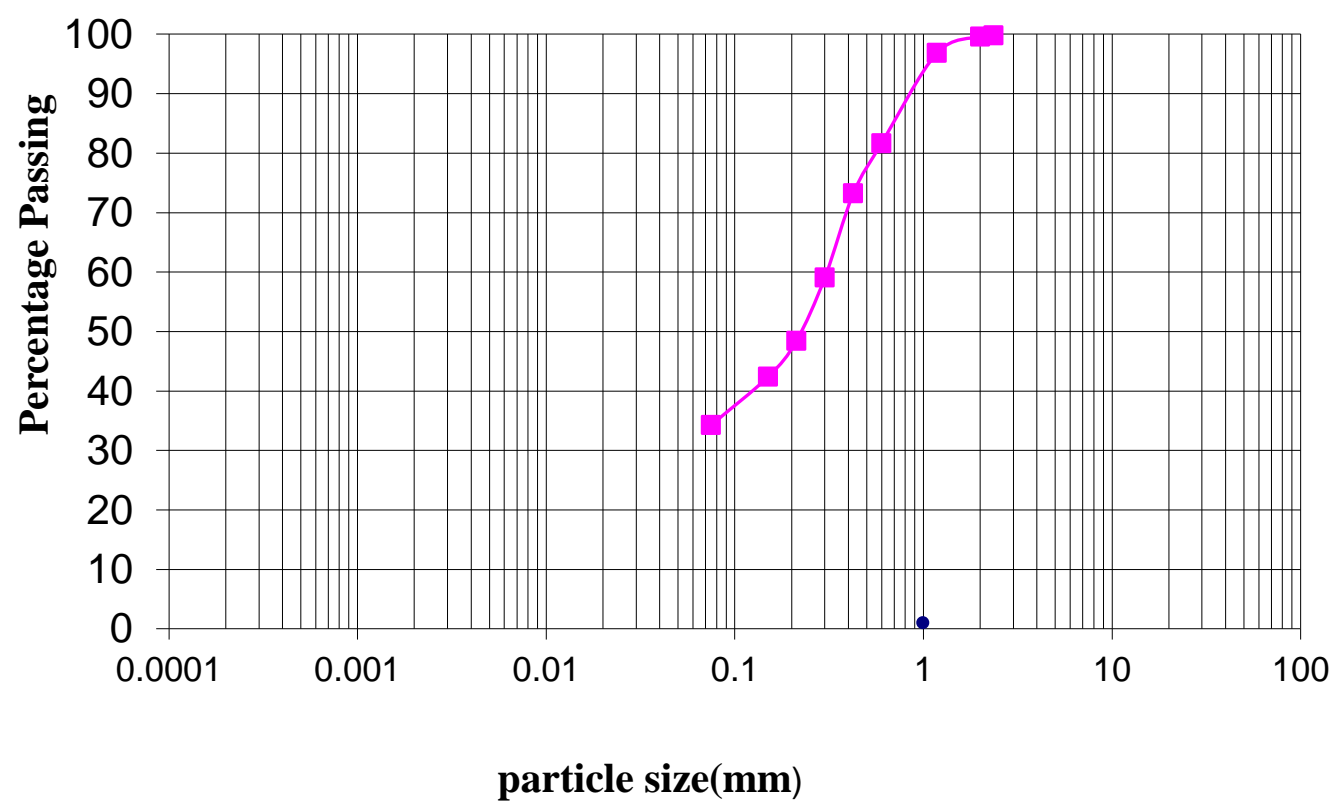

Fig. 1 Particle Size Analysis

\subsection{Preliminary analysis}

The summary of the results of the preliminary analysis of the soil samples is presented in Table 1 .

Table 1 Preliminary analysis of the soil sample

\begin{tabular}{|c|c|c|c|c|c|c|}
\hline Sample & $\begin{array}{c}\text { Natural moisture } \\
\text { content(\%) }\end{array}$ & $\begin{array}{c}\text { Specific } \\
\text { gravity }\end{array}$ & $\begin{array}{c}\text { Liquid } \\
\text { limit (\%) }\end{array}$ & $\begin{array}{c}\text { Plastic } \\
\text { limit (\%) }\end{array}$ & $\begin{array}{c}\text { Plasticity } \\
\text { index (\%) }\end{array}$ & $\begin{array}{c}\text { AASHTO } \\
\text { classification }\end{array}$ \\
\hline Ogiso soil & 15.1 & 2.56 & 33.20 & 14.14 & 19.06 & A-2-6 \\
\hline
\end{tabular}

The natural moisture content of the soil, which is shown in Table 1, is $15.1 \%$. This is a function of the void ratio and the specific gravity of the sample. This indicates that the soil sample contained appreciable amount of moisture which largely depends on the climatic conditions. The specific gravity of the sample is 2.56 . The sample fell within the granular material under the general classification, as the percentage passing of the $0.075 \mathrm{~mm}$ or No 200 sieve was $34.29 \%$, the liquid limit is $33.20 \%$ and the plasticity index is $19.06 \%$. It fell within the A-2 groups. Based on the liquid limit and plasticity index values, the sample was further classified as A-2-6. These values satisfy the AASHTO requirement for A-2-6 soil [16].

\subsection{Atterberg limit test results}

The results of Atterberg limits (liquid limits, plastic limits, plasticity index) with the additives: cement, lime and the combination of cement and lime are presented in Table 2. 
Table 2 Summary of the results of Atterberg limits of the stabilized soil

\begin{tabular}{|c|c|c|c|c|c|c|}
\hline Additives & $\begin{array}{c}\text { Atterberg } \\
\text { Limits }\end{array}$ & $2 \%$ & $4 \%$ & $6 \%$ & $8 \%$ & $10 \%$ \\
\hline \multirow{3}{*}{ Cement } & LL (\%) & 31 & 30 & 32 & 32 & 31 \\
\hline & PL (\%) & 13.69 & 17.17 & 19.56 & 19.20 & 16.89 \\
\hline & PI (\%) & 17.31 & 12.83 & 12.44 & 12.80 & 14.11 \\
\hline \multirow{3}{*}{ Lime } & LL (\%) & 35 & 34.9 & 32.7 & 32 & 30.9 \\
\hline & PL (\%) & 21.74 & 21.75 & 19.57 & 19.10 & 16.89 \\
\hline & PI (\%) & 13.26 & 13.15 & 13.13 & 12.9 & 14.01 \\
\hline \multirow{3}{*}{$\begin{array}{c}\text { Lime } \\
\text { and } \\
\text { cement }\end{array}$} & LL (\%) & 32 & 34.6 & 35 & 33.6 & 35.2 \\
\hline & PL (\%) & 19.51 & 18.53 & 21 & 16.92 & 16.91 \\
\hline & PI (\%) & 12.44 & 16.07 & 14 & 16 & 18 \\
\hline
\end{tabular}

where: $\mathrm{LL}=$ liquid limit, $\mathrm{PL}=$ plastic limit, $\mathrm{PI}=$ plastic index

The values of the liquid limits, plastic limit, plasticity index of the soil samples are $33.20 \%, 14.14 \%$ and $19.06 \%$ respectively for the natural soil. From the AASHTO guide [16], plastic index (PI) ranging from 0 to 3 indicate non plastic soil, between 3-15, it is slightly plastic, between $15-30$, it is medium plastic and when it is $>30$, it is highly plastic. This shows that the soil in the study area is medium plastic. From Table 2, it can be seen that the addition of the stabilizing agents at 2\%, 4\%, 6\%, $8 \%$ and $10 \%$ caused a difference in the liquid limit and plastic index, whereby the plastic index reduces from $17.31 \%$ to $12.83 \%$ for cement and for lime from 13.26 to $13.15 \%$. This reduction shows improvement in the soil.

\subsection{Compaction characteristics}

The variation of Maximum Dry Density (MDD) with cement, lime and combination of cement and lime content is presented in Fig. 2., while the variation of OMC with cement, lime and combination of cement and lime content is shown in Fig. 3.

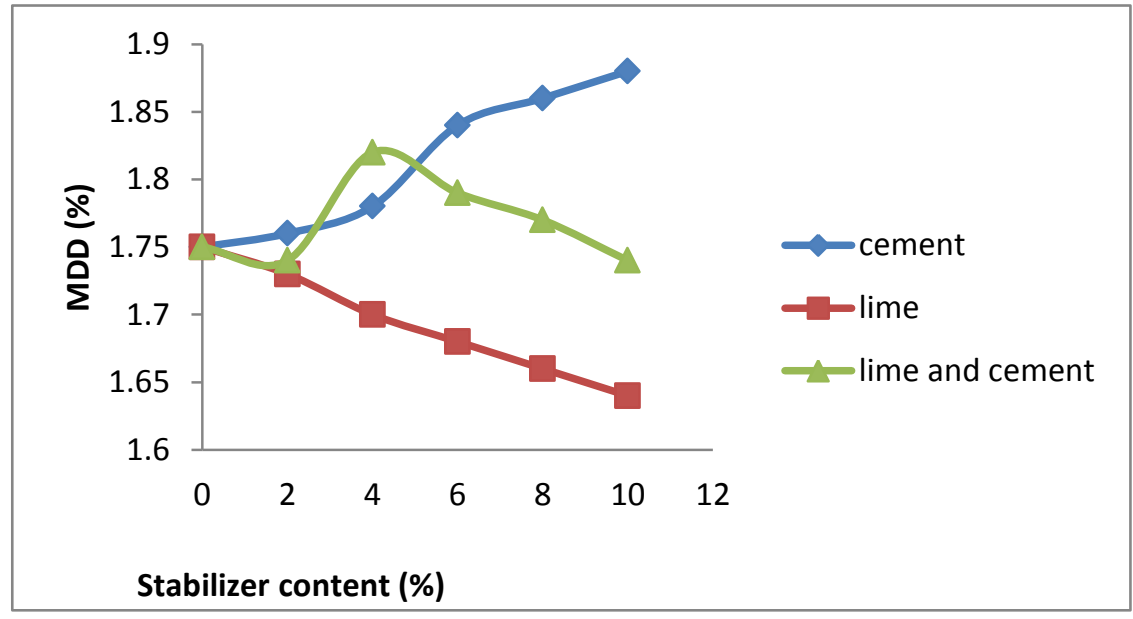

Fig. 2. Variation of MDD with cement, lime and combination of cement and lime content 


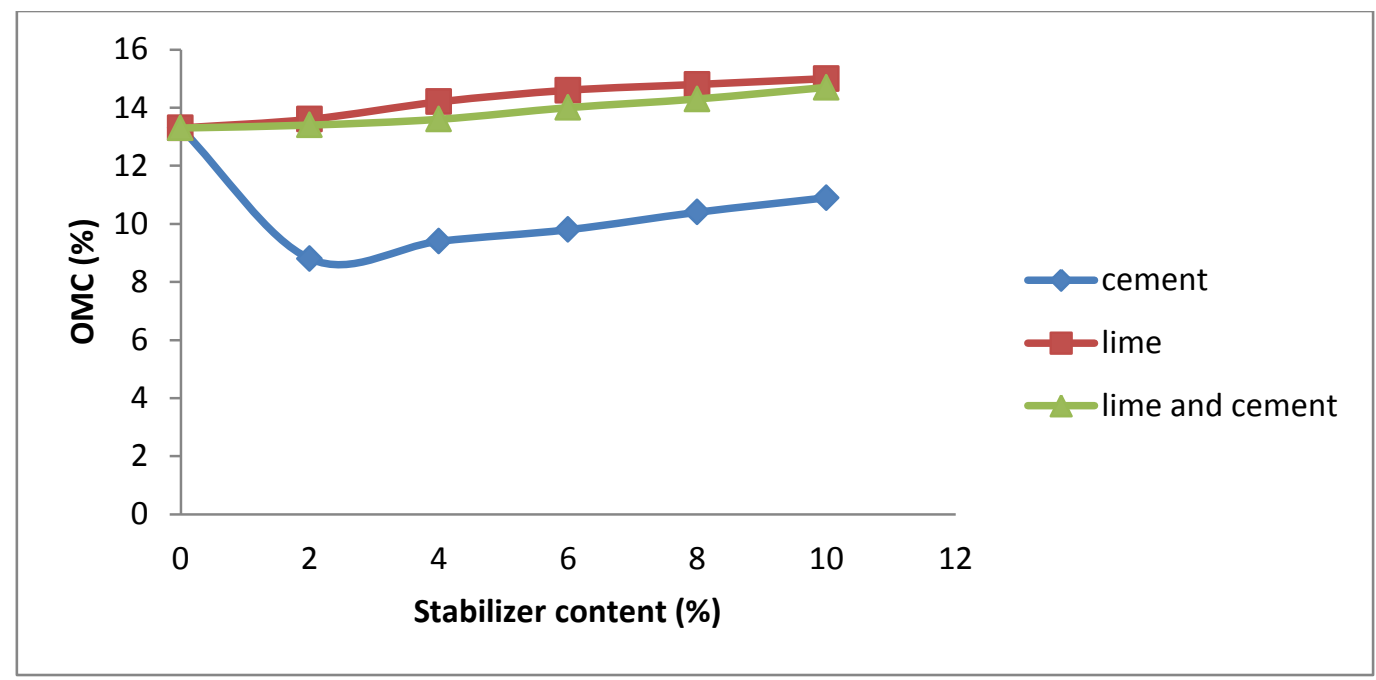

Fig. 3 Variation of OMC with cement, lime and combination of cement and lime content.

The MDD results for lime in Fig. 2 decreases with the increase in lime content and this conforms to the research work of [18]. The increase in OMC for lime in Fig. 3 conforms with the findings of [19]. Moreover, these results obtained show that the moisture density relationship follows a trend of decreasing maximum dry density (MDD) /increasing Optimum moisture content (OMC) for lime at the Standard Proctor compaction energy.

\subsection{California Bearing Ratio (CBR) Results}

The relationship between the CBR with cement, lime and combination of cement and lime content is presented in Fig.4.

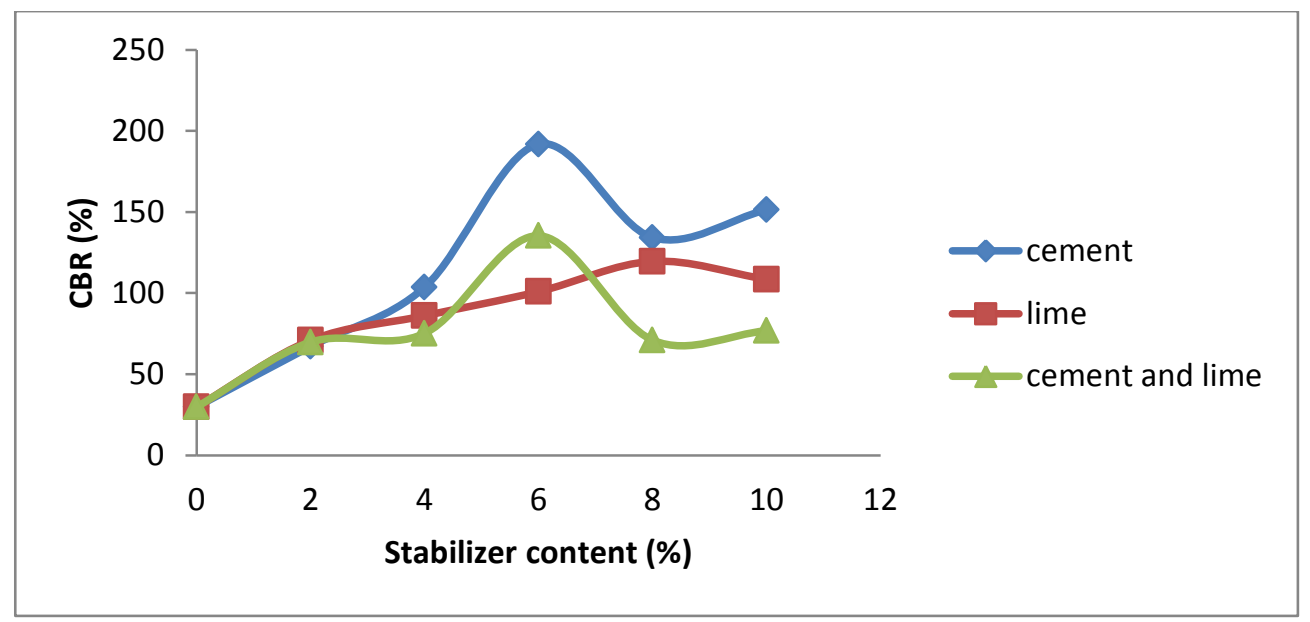

Fig.4 Relationship between the CBR with cement, lime and combination of cement and lime content.

In Fig.4, the soaked CBR values in the soil with cement content and the combination of cement and lime content increased to $191.80 \%$ and $135.36 \%$ respectively at $6 \%$ stabilization. While the CBR values for lime content only is $119.57 \%$ at $8 \%$ stabilization. This shows that the load bearing capacity of the samples increased considerably with the increments of cement content. For the lime stabilization, the soaked CBR of the lime stabilized sample also increased to $119.57 \%$ at $8 \%$ stabilization. These values indicate that the lateritic soil in the study area meets the general standard acceptable limit for construction of embankments, as they are in conformity with the Federal Ministry of Work (FMW) general standard acceptable limit for construction of embankments and sub-grade [20].

\subsection{CONCLUSION}

Based on the results of this study, the increased bearing capacity incorporated into the soil on the addition of the stabilizing agents show soil improvement and that both cement and lime are good stabilizing agents. Hence, it makes the soil a better material for sub-base and base material for road pavement construction. The CBR test result shows that cement stabilization is more effective stabilization method than lime stabilization. However, but due to the cost effectiveness of cement for construction work, 
lime can be used since between $6 \%-8 \%$ it shows great percentage increase in strength which is similar to that of cement at $4 \%$ $6 \%$, so it can serve the same purpose as cement thereby saving cost.

\section{REFERENCES}

[1] Abubakar, J.B. (2006), “Geotechnical study of lateritic soil in tipper garage, Katampe Area” Federal Capital Territory, Abuja, Journal of Geo-Engineering, Abuja, Vol.2, pp 4 -34

[2] Amadi, A N. and Oke, S. A.(2008), "An assessment of the geotechnical properties of the subsoil of part of the Federal University of Technology, Minna, Gidankwano campus for foundation design and construction”, Journal of Science, Education and Technology, Minna, Vol. 1, pp 87-102

[3] Lopes, L.S.E.; Szeligal, L.; Casagrande, M.D.T.; Motta, L.M.G. (2012), “Applicability of coal ashes to be used for stabilized pavement base, State-of-the Art and Practice in Geotechnical Engineering”, American Society of Civil Engineer (ASCE), Geotechnical Special Publication, pp 2854-3862

[4] Gidigasu, M.D. (1976), “Laterite Soil Engineering”, $3{ }^{\text {rd }}$ Edition, Elsevier Scientific Publishing Company, New York

[5] Rossiter, D.G. (2004), "A Compendium on line soil survey information: soil classification for soil survey", 3 rd Edition. London. Vol. 4, pp 12-16.

[6] Badmus, B. S. (2010), "Plasticity and Compressibility Characteristics of lateritic soil from South Western Nigeria. Journal of Natural Sciences Engineering and Technology, Ibadan, Vol 9, pp.23-26

[7] Ola, S.A (1975), "Stabilization of Nigerian Laterite Soil with Cement, Bitumen and Lime,

Proceedings of the African Soil Conference, Dublin, Vol. 1

[8] Pousette, K., Macsik, J. and Jacobsson, A. (2000). Peat soil samples stabilized in Laboratory experiences from manufacturing and testing. Proceeding of dry mix methods for deep stabilization, Stockholm, pp 85-92.

[9] Spangler, M. G. and Handy, R.L.(1982), “Soil Engineering”, Fourth Edition, Harper and Row Publishers, New York

[10] Osula, D.O.A. (1991), "Lime Modification of Problem Laterite", Engineering Geology,Elsevier Science Publishers B.V., Amsterdam, Vol. 30: pp141-154

[11] Bell, F.G. (1996), “Lime stabilization of clay minerals and soils”. Journal of Engineering Geology, London, Vol. 42, pp 223227

[12] Sariosseiri, F. and Muhunthan, B. (2009). "Effect of cement treatment on geotechnical properties of some Washington State soils”. Engineering Geology, U.S.A, Vol. 104 No2, pp 119-125.

[13] Amu, O. and Komolafe, I. A. (2012), "The suitability and lime stabilization requirement of some lateritic soil samples as pavement”, International Journal of Pure Applied Science Technology, Ibadan, Vol., pp 29 - 46

[14] Nicholas, J.G. and Lester, A.H. (1999), “Traffic and Highway Engineering, $2^{\text {nd }}$ Edition, Brooks/Cole Publishers, USA

[15] Arora, K. R. (2009), "Soil mechanics and foundation engineering- Geotechnical Engineering" Standard Publishers Distributors, Delhi

[16] American Association of State Highway and Transportation Officials (AASHTO) (1993), AASHTO Guide for Design of Pavement Structures, Washington, D. C.

[17] British Standard Institution (BSI), (1990), "Methods of Testing for soils for Civil Engineering Purposes" BS (1377), London, pp 143.

[18] Osula, D.O.A. (1989), "Evaluation of Admixture Stabilization of problem laterite. Journal of Transportation Engineering, Division, ASCE, No 115, Vol 6, pp 674-687. 
[19] Ola, S. (1978). "Geotechnical properties of some stabilized Nigeria lateritic soil”, Quarterly Journal of Engineering, Geology and Hydrogeology, Oyo State, Vol. 11, No.2, pp 145-160

[20] Federal Ministry of Works General Specifications (FMWGS) (1970) "Roads and Bridges Works". Federal Government of Nigeria, Lagos, Nigeria 